\title{
Effect of Different Levels of Sodium Chloride and Glucose on Fermentation of Sardines (Sardinella brasiliensis) by Lactobacillus sakei 2 a
}

\author{
Milton Luiz Pinho Espirito Santo ${ }^{1 *}$, Cristiane Lisboa ${ }^{1}$, Fernanda Gonçalves Alves ${ }^{1}$, Daniela \\ Martins $^{1}$, Luiz Henrique Beirão ${ }^{2}$, Ernani Sebastião Sant'Anna ${ }^{2}$ and Bernadette Dora \\ Gombossy de Melo Franco ${ }^{3}$ \\ ${ }^{1}$ Departamento de Química; Fundação Universidade Federal do Rio Grande; 96.201-900; Rio Grande - RS - \\ Brazil. ${ }^{2}$ Departamento de Ciência e Tecnologia de Alimentos; Centro de Ciências Agrárias; Universidade Federal \\ de Santa Catarina; Florianópolis - SC - Brazil. ${ }^{3}$ Departamento de Alimentos e Nutrição Experimental; Faculdade \\ de Farmácia; Universidade de São Paulo; São Paulo - SP - Brazil
}

\begin{abstract}
Lactobacillus sakei $2 a$ is a bacteriocin producer strain. In this study, it's effects as a starter culture in the curing process of sardine (Sardinella brasiliensis) fillets were studied at different concentrations of $\mathrm{NaCl}(2,4,6 \%)$ and glucose (2, 4\%). After 21 days of fermentation, the spoilage microorganisms population reached 9.7 Log $_{10} C F U g^{-1}$ corresponding to $6 \% \mathrm{NaCl}$ and $4 \%$ glucose. With no addition of glucose and starter culture, sardine fillets began spoilage 72 hours after fermentation, even when $6 \% \mathrm{NaCl}$ was used. Little differences were observed in lactic acid production when 2 and 4\% glucose were added, since total acidity was 1.32 and $1.34 \%$ respectively, the experiments with $6 \% \mathrm{NaCl}$ presented the best results. Initial $\mathrm{pH}$ of sardine fillets was 6.0 and after 21 days pH values were 3.8, 3.9 and 4.0 for the experiments with 2, 4 and 6\% $\mathrm{NaCl}$ respectively. This could have been due to the inhibitory properties of $\mathrm{NaCl}$ over the spoilage microorganisms. After 21 days of the fermentation, the levels of lactic acid bacteria $(\mathrm{LAB})$ were $14.5 \log _{10} \mathrm{CFU} \cdot \mathrm{g}^{-1}$.
\end{abstract}

Key words: Sardinella brasiliensis, Lactobacillus sakei 2a, fermented fish

\section{INTRODUCTION}

Fish fermentation is widely used for production of fish sauces and fish pastes (Olympia et al., 1992 and Ostergaard et al., 1998). Sensory attributes of the product undergo major changes during fermentation, due to the high level of salt involved (addition of up to 30\%) and the high rate of proteolysis which is enhanced by high fermentation temperatures (Twddy et al., 1987). A key factor limiting fish utilization is its extreme perishability. In tropical countries the problem posed by the intrinsic suitability of fish flesh as a medium for microbial growth is further compounded by a high ambient temperature. (Morzel et al., 1997; Virulhakul, 2000 and Gory et al., 2001). The present study examined the use of Lactobacillus sakei $2 \mathrm{a}$ on the fermentation of sardine fillets. Fish-NaCl-glucose system was used to evaluate the factors that favoured a fast lactic fermentation.

Author for correspondence 


\section{MATERIALS AND METHODS}

\section{Formulation of sardine model system}

Fresh sardine were deheaded, degutted, filleted and stored at $30{ }^{\circ} \mathrm{C}$. The fillets were then divided into $300 \mathrm{~g}$ portions in sterile flasks, and different concentration of $\mathrm{NaCl}$ and glucose were added. Concentrations tested (expressed on total weight of sardine and water mixture) were 2, 4 and $6 \%$ $\mathrm{NaCl} ; 2$ and $4 \%$ glucose. Two independent experiments were performed in duplicate, in which only one parameter ( $\mathrm{NaCl}$, glucose) was varied. The system inoculated with the bacterial strain at a level of $10^{8} \mathrm{CFU} . \mathrm{g}^{-1}$ and fermented at $23-24{ }^{0} \mathrm{C}$ for 21 days. The speed and efficiency of the lactic fermentation was monitored by the rate of $\mathrm{pH}$ decrease and the balance between lactic acid bacteria (LAB) counts and total aerobic counts using Plate Count Agar (PCA, Oxoid CM 463). The slow growing LAB on PCA was excluded from the total spoiler count. The competition between LAB and spoilers is expressed as the log ratio between the counts on MRS and PCA media (Zhang and Holley, 1999).

\section{Bacterial strain}

Lactobacillus sakei 2a, isolated from "lingüiça" (a typical Brazilian meat product), was kindly provided by Faculdade de Ciências Farmacêuticas, Universidade de São Paulo (De Martinis and Franco, 1997; Gonzáles-Fernandez et al., 1997).

\section{Morphophysiological and biochemical characteristics of strain}

The strain (L. sakei 2a) was characterized by Gram-reaction, morphology (phase-contrast microscopy), growth at 8,15 and $45{ }^{\circ} \mathrm{C}$ and $\mathrm{pH}$ 3.9 , halophilism at $6.5,7$ and $10 \% \mathrm{NaCl}$, motility, catalase test $\left(20 \% \quad \mathrm{H}_{2} \mathrm{O}_{2}\right)$, Voges-Proskauer reaction (MR-VP Medium), methyl red test, formation of $\mathrm{H}_{2} \mathrm{~S}$, gas from glucose, lysine decarboxylase, indole test, gelatin liquefaction, bacteriocins production and carbohydrates fermentation (acid production). Glucose fermentation and gas production were tested in MRS broth with $1 \%$ glucose. The detection of bacteriocins produced by $L$. sakei $2 \mathrm{a}$ was examined using the well - diffusion assay (Lewus et al., 1991). A modification of the well - diffusion assay method was employed as follow. Cell-free supernatant from MRS broth was collected by centrifugation at $9.77 \mathrm{x} \mathrm{g}$ for $10 \mathrm{~min}$. The supernatant was neutralized to $\mathrm{pH} 7$ with $1 \mathrm{~N}$
$\mathrm{NaOH}$ and sterilized by filtration (membrane $\mathrm{GV}$ Millipore - 0.22- $\mu \mathrm{m}$ ). Pour plates were prepared from BHI containing $1 \%$ agar seeded with $10^{6}$ UFC. $\mathrm{mL}^{-1}$ of Listeria monocytogenes Scott A. Wells cut into the pour plates with sterile straws were filled with $40 \mu \mathrm{L}$ of the culture supernatant. The plates were incubated anaerobically overnight at $30^{\circ} \mathrm{C}$. Inhibition was detected by a zone of clearing around the supernatant well (De Man et al., 1960 and Lewus et al., 1991).

\section{Growth of $L$. sakei $2 \mathrm{a}$}

Viable counts of $L$. sakei 2 a were determined by plating on MRS agar (Oxoid CM 361). Culture was grown in MRS for $48 \mathrm{~h}$ at $30{ }^{\circ} \mathrm{C}$. The broth was centrifuged and the cell pellet was resuspended in diluent containing $1 \%(\mathrm{w} / \mathrm{v})$ peptone in sterile deionized water. Serial dilutions were made and the optical density was measured at $\mathrm{OD}_{520 \mathrm{~nm}}$ using spectrophotometer and the cell suspension was spread-plated on MRS agar for enumeration. A linear relationship between the cell concentrations and optical densities was obtained around $10^{8}-10^{9} \mathrm{CFU} . \mathrm{mL}^{-1}$ levels (Lewus et al., 1991).

\section{Microbiological analyses of sardine fillets}

Samples of sardine fillets $(10 \mathrm{~g})$ were aseptically removed and homogenized for $3 \mathrm{~min}$ in peptone water $(90 \mathrm{~mL})$. The homogenate was serially diluted and used for enumeration of microorganisms. Total bacterial counts were determined by spread-plating on to Plate Count Agar (PCA) and incubating at $30^{\circ} \mathrm{C}$ for $48 \mathrm{~h}$. Enterococcus was determined by spread plating on to KF agar (Merck 10707), Staphylococcus aureus was enumerated by spread-plating on to BairdParker Medium (Oxoid CM 275) and coliforms on to Violet Red Bile agar (Oxoid CM 107). Presence of Salmonella was assessed following the procedure described in APHA (1992): after enrichment in $0.1 \%$ peptone water overnight and in Rappaport-Vassiliadis broth (Oxoid CM 669) at $37^{0} \mathrm{C}$ for $24 \mathrm{~h}$, samples were streaked on Brilliant Green-Agar (Oxoid CM 263) and plates were incubated at $37{ }^{\circ} \mathrm{C}$ for $24 \mathrm{~h}$.

\section{Chemical analysis}

The proximate composition (moisture, protein, fat and ash) of the raw sardines sample used in the present experiment was determined using standard methods (AOAC, 1995). 


\section{Total titratable acidity (TTA)}

Using the same homogenate prepared for the determination of $\mathrm{pH}$, the TTA was measured by titrating against $0.1 \mathrm{~N}$ sodium hydroxide to a final $\mathrm{pH}$ of 8 . The $\% \mathrm{w} / \mathrm{w}$ lactic acid in the sample was calculated by multiplying the volume of alkali $(\mathrm{mL})$ by the factor 0.09 (AOAC, 1995). This assumed that all the acid present in the sample was lactic acid.

Total soluble nitrogen and free amino nitrogen The samples were analyzed for total soluble nitrogen (TSN), protein (total $\mathrm{N} \times$ 6.25) and free amino nitrogen, FAN ( $\alpha$-amino nitrogen) content using standard methods (AOAC, 1995).

\section{Physical analysis}

Each sample $(10 \mathrm{~g})$ was blended with $90 \mathrm{~mL}$ deionised water. The $\mathrm{pH}$ of the homogenized samples was measured according to a direct method, using a pH meter model 240 (Corning, New York, USA). Each measurement represented the mean of three readings. Samples were analyzed on a wet weight (as) basis. Average pH drop between $\mathrm{t}=21$ days and $\mathrm{t}=0$ days were calculated.

\section{Data analysis}

The significance of effects of different process parameters and combinations of conditions in simulation assays were determined by 1- way analysis of variance $(\mathrm{p}<0.01)$. Data were expressed as means of three replicates and standard errors of means (Statsoft Inc./Computer Program Manual).

\section{RESULTS AND DISCUSSION}

\section{Raw material}

The proximate composition of the raw sardines sample used in the experiment was protein 19\%, fat $3.1 \%$, moisture $73.4 \%$ and ash $1.9 \%$ (Table 1). Sardinella sp. traditionally had fat values from $2 \%$ (spring) to 8.6\% (autumn) and moisture from 66 to $84 \%$ (similar to the marine fish) (Badolato et al., 1994).

Table 1 - Composition of sardine fillets

\begin{tabular}{lrrrrr|c}
\hline & $\mathbf{R}_{\mathbf{1}}$ & $\mathbf{R}_{\mathbf{2}}$ & $\mathbf{R}_{\mathbf{3}}$ & $\mathbf{X}$ & $\mathbf{D p}$ \\
\hline Moisture & 72.9 & 73.5 & 73.7 & 73.4 & \pm 0.39 \\
Fat & 2.0 & 3.0 & 4.2 & 3.1 & \pm 0.89 \\
Protein & 19.7 & 19.6 & 17.7 & 19.0 & \pm 0.88 \\
Ash & 2.0 & 1.9 & 1.9 & 1.9 & \pm 0.01 \\
\hline
\end{tabular}

$\mathrm{R}_{1,2,3}$ : samples.

$\mathrm{X}$ : average, Dp: standard deviation.

The microbial analysis of the raw sardines is shown in Table 2. The total aerobic counts (PCA) in the raw material ranged from $3.5 \times 10^{2}$ to $1.1 \times 10^{4} \mathrm{CFU} \cdot \mathrm{g}^{-1}$. Enterococcus counts were below $\log _{10} 4 \times 10^{2}$ CFU.g. ${ }^{-1}$. Staphylococcus aureus counts were $<10^{2}$ CFU. $\mathrm{g}^{-1}$. Salmonella were not detected.

\footnotetext{
Morphophysiological and biochemical characteristics of $L$. sakei $2 \mathrm{a}$

The strain was characterized as cocci Grampositive, rods in short chains (1-7 cell units), nonsporing and nonmotile. The colonies showed white to cream in color, circular shape, smooth, brilliant, convex, creamy consistency and diameter between 0.5 and $1.0 \mathrm{~mm}$. L. sakei $2 \mathrm{a}$ was
}

aerotolerant and grew at 7 and $10 \% \mathrm{NaCl}$, at $\mathrm{pH}$ 3.9 and 8 and $15{ }^{0} \mathrm{C}$ but not at $45{ }^{\circ} \mathrm{C}$. The biochemical characteristics of the L.sakei $2 \mathrm{a}$ are shown in Table 4.

\section{Optimization of fermentation parameters}

Results of the chemical analysis, as expected, showed that acidity increased as fermentation progressed (Table 4). The $\mathrm{pH}$ values decreased in all samples. Final $\mathrm{pH}$ and $\%$ titrable acidity obtained after 21 days of fermentation were $\mathrm{pH} 4$ and $2.55 \%$ respectively $(2 \% \mathrm{NaCl}$ and $2 \%$ glucose). The results showed that the $\mathrm{pH}$ decreased with the glucose content $(2 \% \mathrm{w} / \mathrm{w})$, nevertheless when the concentration of $\mathrm{NaCl}$ was increased from 2 to $6 \%$, the fermentation rate 
reduced. Using $2 \% \mathrm{NaCl}$ with $2 \%$ glucose resulted in an acidity increase to approximately $1.21 \%$ after 7 days and $2.55 \%$ after 21 days. Addition of $6 \% \mathrm{NaCl}$ resulted in an acidity increase to $0.74 \%$ after 7 days and $1.32 \%$ after 21 days. However, the reproducibility of fermentation rates between different batches was quite variable in the allimportant first 2-day period. This fact could be attributed to differing degrees of freshness of the commercially obtained fish and its effect on the LAB. The total soluble nitrogen content of all the samples increased slightly with increasing fermentation time. A similar observation was made during a study on "Bakasang"; a traditional Indonesian fermented fish sauce (Ijong and Ohta, 1996).

Table 2 - Microbiological characteristics of raw material

\begin{tabular}{|c|c|c|c|c|}
\hline & $\mathrm{R}_{1}$ & $\mathrm{R}_{2}$ & $\mathrm{R}_{3}$ & $\mathrm{X}$ \\
\hline $\begin{array}{c}\text { Aerobic mesophilic bacteria } \\
\left.\text { (CFU. } \mathrm{g}^{-1}\right)\end{array}$ & $3.5 \times 10^{2}$ & $1.1 \times 10^{4}$ & $4.4 \times 10^{3}$ & $5.2 \times 10^{3}$ \\
\hline $\begin{array}{c}\text { Coliforms } \\
\text { (MPN. g-1) }\end{array}$ & $<3$ & $<3$ & $<3$ & $<3$ \\
\hline $\begin{array}{l}\text { Fecal coliforms } \\
\text { (MPN. g-1) }\end{array}$ & $<3$ & $<3$ & $<3$ & $<3$ \\
\hline $\begin{array}{l}\text { St. aureus } \\
\text { (CFU. g-1) }\end{array}$ & $<10^{2}$ & $<10^{2}$ & $<10^{2}$ & $<10^{2}$ \\
\hline $\begin{array}{l}\text { Enterococcus } \\
\left(\text { CFU. } \mathrm{g}^{-1}\right)\end{array}$ & $3.5 \times 10^{2}$ & $3.5 \times 10^{2}$ & $3.5 \times 10^{2}$ & $3.5 \times 10^{2}$ \\
\hline Salmonella sp. & Absence & Absence & Absence & Absence \\
\hline
\end{tabular}

$\mathrm{R}_{1,2,3}$ : means of three samples.

$\mathrm{X}$ : average

Table 3 - Biochemical characteristics of the Lactobacillus sakei $2 \mathrm{a}$

\begin{tabular}{|c|c|}
\hline Production & Reactions \\
\hline Catalase & - \\
\hline Voges-Proskauer & + \\
\hline Gas from glucose & - \\
\hline $\mathrm{H}_{2} \mathrm{~S}$ & - \\
\hline Indole & - \\
\hline Lysine decarboxylase & + \\
\hline Methyl red & + \\
\hline Bacteriocins & + \\
\hline \multicolumn{2}{|l|}{ Fermentation } \\
\hline Lactose & - \\
\hline Sucrose & + \\
\hline Glucose & + \\
\hline Rhamnose & - \\
\hline Xylose & - \\
\hline Arabinose & + \\
\hline Raffinose & - \\
\hline Galactose & + \\
\hline Maltose & - \\
\hline Trehalose & - \\
\hline Sorbitol & - \\
\hline
\end{tabular}


The changes of total free amino nitrogen were similar to the changes in total soluble nitrogen (Roig - Sagués and Eerola, 1997). Samples containing $2 \% \mathrm{NaCl}$ showed higher values of both total soluble nitrogen and free amino nitrogen than those containing $\mathrm{NaCl}$ at $6 \%$ regardless of the glucose concentration in the samples. The increases of both total soluble nitrogen and total free amino nitrogen during processing of sardine could be attributed to the combined effects of autolysis and microbial degradation of the fish muscle. The evidence for autolysis in this experiment was provided by changes in the ratio of free amino nitrogen to total soluble nitrogen (Fig.1). This ratio increased during the fermentation period, indicating the occurrence of autolysis. Samples produced with $6 \% \mathrm{NaCl}$ showed less autolysis than samples with $2 \% \mathrm{NaCl}$. During the ripening of fermented sardines, biogenic amines may be formed by the action of bacterial descarboxylases of microorganisms originating from raw material (Silva et al., 1998). The inoculation with starter culture significantly inhibited the growth of spoilage microorganisms, maintaining the samples in relatively good microbiological quality throughout the study (Fig.2). In the inoculated samples, LAB counts increased to $5.0 \log _{10} \mathrm{CFU} . \mathrm{g}^{-1}$ during the 21 days. The results showed that $\mathrm{LAB}$ predominated almost throughout the seven-day fermentation period while spoilage microorganisms were present only at the early stages of the fermentation. The viability of non-acid formers (NAF) existed only for a short period of time since the environment would be inhibitory to them as the fermentation progressed due to the production of lactic acid.

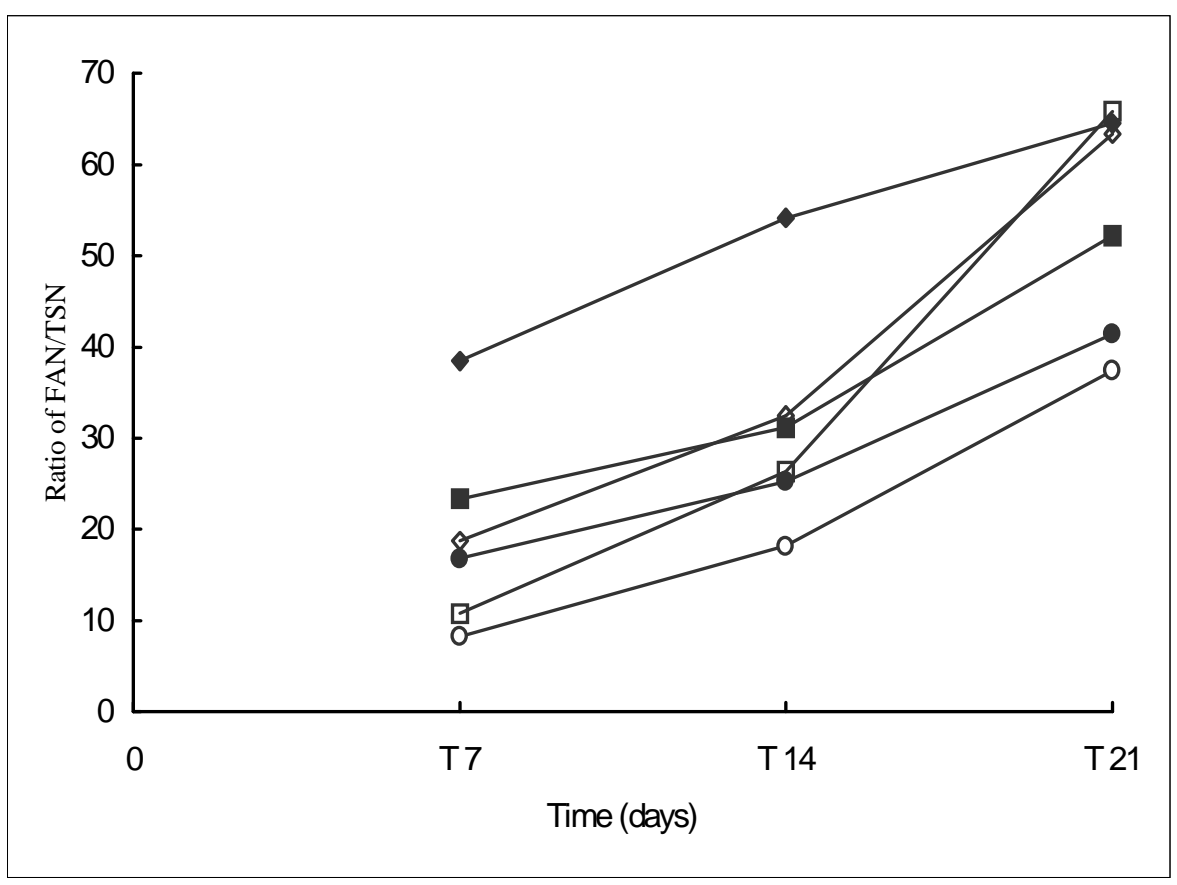

Figure 1 - Ratio of free amino nitrogen and total soluble nitrogen during fermentation of sardine.

Simbols: $\bullet 2 \%$ glucose- $2 \% \mathrm{NaCl},-2 \%$ glucose- $4 \% \mathrm{NaCl}, \bullet 2 \%$ glucose- $6 \% \mathrm{NaCl}, \diamond 4 \%$ glucose- $2 \% \mathrm{NaCl}, \square 4 \%$ glucose- $4 \% \mathrm{NaCl}, \circ 4 \%$ glucose- $6 \% \mathrm{NaCl}$ 
Table 4 - Changes in acidity (\% lactic acid) during fermentation of sardine

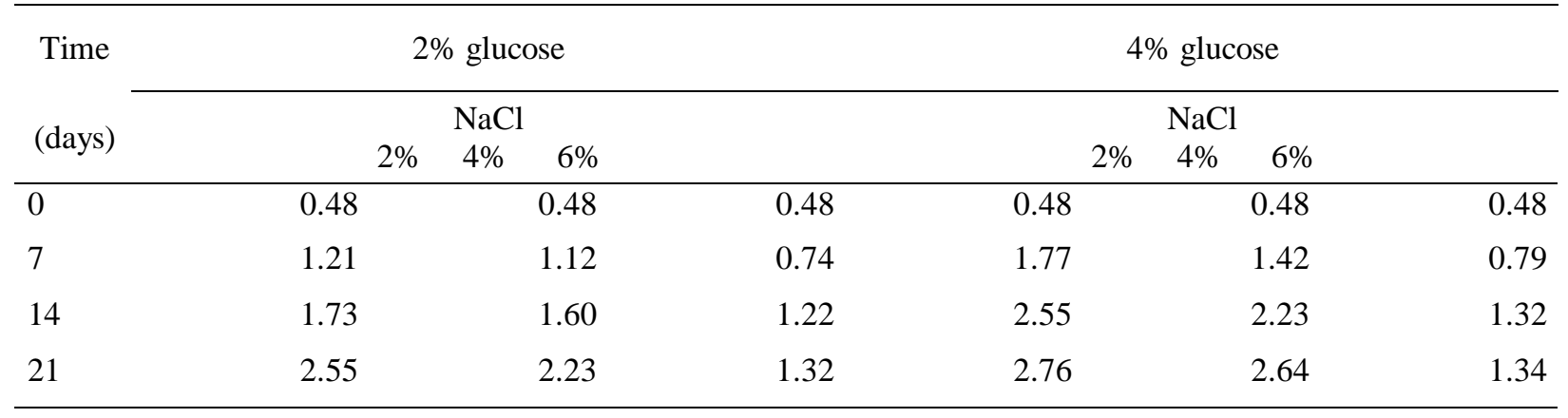
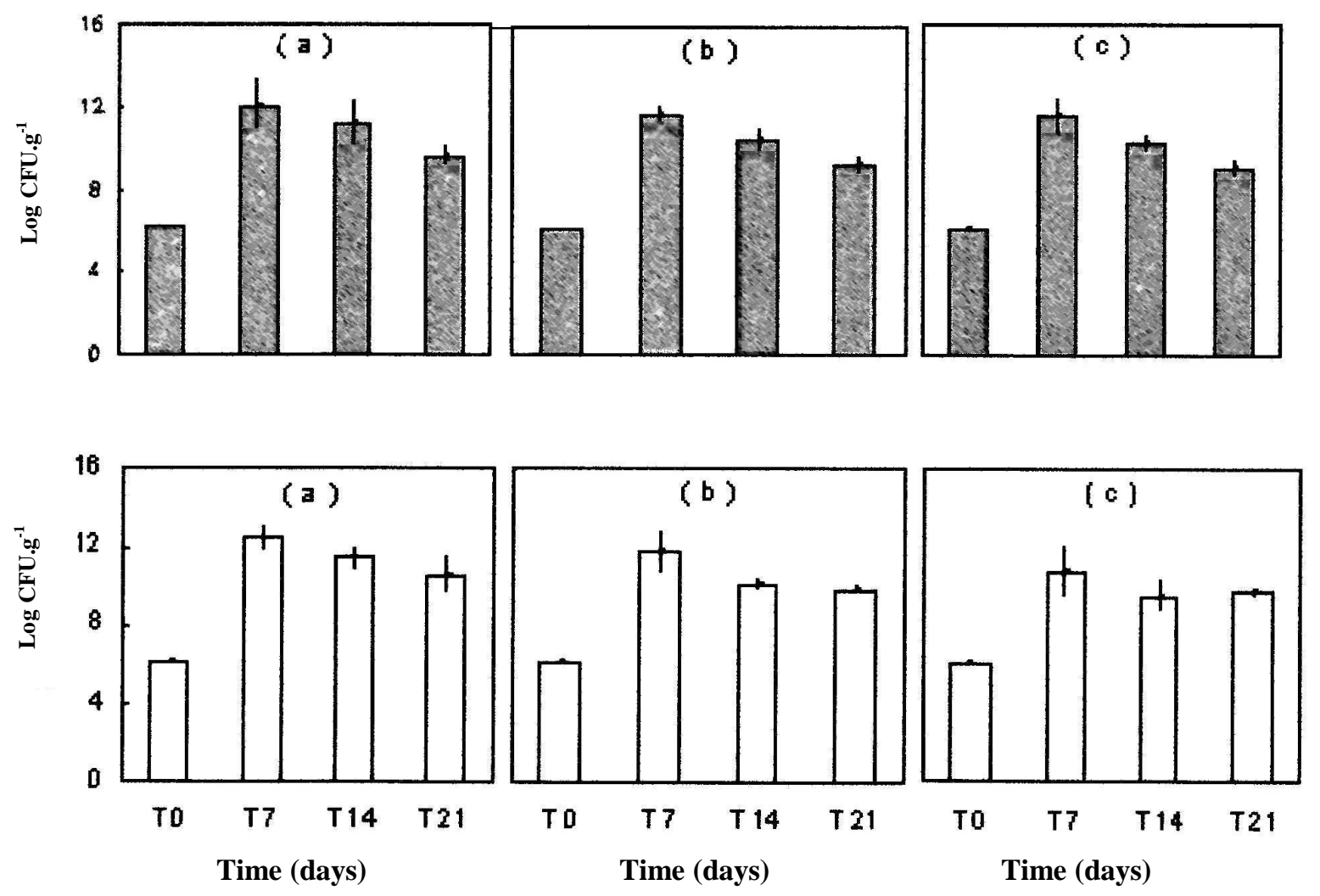

Figure 2 - Changes in plate count agar (PCA) during growth of spoilage microorganisms in fermented sardine. Samples were formulated with combinations of various proportions of $\mathrm{NaCl}$; (A) $2 \%$, (B) $4 \%$, (C) $6 \%$ and glucose; $2 \square, 4 \% \square$.

\section{CONCLUSIONS}

The inoculation with Lactobacillus sakei 2a significantly inhibited the growth of spoilage microorganisms, maintaining the samples in relatively good microbiological quality throughout the study. The production of competitive and bacteriocinogenic lactic acid bacteria may well provide an additional hurdle to improve fish preservation by natural means.

The implementation of biopreservation in a certain food system depends on the influence of formula and technology on the performance of bacteriocinproducing cultures as well as the adaptation of the 
culture to the specific ecological habitat of the food.

\section{ACKNOWLEDGEMENTS}

We would like to thank Mr. Luiz Henrique Beirão and Mr. Ernani S'antanna for their assistance with some of the experiments referred to in this paper.

\section{RESUMO}

Lactobacillus sakei 2a é uma cepa produtora de bacteriocinas e, neste estudo, procurou-se observar seus efeitos como cultivo iniciador na fermentação de filés de sardinha (Sardinella brasiliensis) em diferentes concentrações de $\mathrm{NaCl}(2,4,6 \%)$ e glicose $(2,4 \%)$. Com 21 dias (fermentação), os microrganismos deterioradores atingiram 9,7 $\log _{10}$ UFC. ${ }^{-1}$, correspondente a $6 \% \mathrm{NaCl}$ e $4 \%$ de glicose. Sem a adição do starter e da glicose, a deterioração (filés) iniciou a partir de 72 horas, mesmo quando foi utilizado $6 \% \mathrm{NaCl}$. Pouca diferença foi observada na produção de ácido lático quando se adicionou 2 e $4 \%$ de glicose, já que a acidez atingiu 1,32 e $1,34 \%$, respectivamente $(6 \%$ $\mathrm{NaCl}$ ), os quais apresentaram os melhores resultados. $\mathrm{O} \mathrm{pH}$ inicial dos filés foi $6 \mathrm{e}$, ao término de 21 dias, atingiu 3,8, 3,9 e 4, equivalente aos experimentos com 2, 4 e $6 \% \mathrm{NaCl}$. Este comportamento pode ser atribuído ao poder inibidor do $\mathrm{NaCl}$ sobre a microbiota deterioradora. Ao término de 21 dias de fermentação, a concentração de bactérias ácido láticas foi $14,5 \log _{10}$ UFC. $\mathrm{g}^{-1}$.

\section{NOTATIONS}

AOAC - Association of Official Analytical Chemists

APHA - American Public Healt Association

BHI - Brain Heart Infusion

CFU - Colony Forming Units

FAN - Free Amino Nitrogen

LAB - Lactic Acid Bacteria

MRS - Man, Rogosa and Sharpe

MR-VP - Methyl Red - Voges Proskauer

$\mathrm{NaCl}$ - Sodium Chloride

NAF - Non-acid Formers

PCA - Plate Count Agar

TSN - Total Soluble Nitrogen
TTA - Total Titratable Acidity

$\mu \mathrm{m}$ - Micrometer

$\mu \mathrm{L}$ - Microlitre

w/w - weight/weight

\section{REFERENCES}

Association of Official Analytical Chemists (1995), Official Methods of Analysis. $16^{\text {th }}$ ed. W. Horwitz (Ed.), Washington.

Badolato, E. S. G.; Carvalho, J. B.; Amaral Mello, M. R. P.; Tavares, M.; Campos, N. C.; Aued-Pimentel, S. and Morais, C. (1994), Composição centesimal de ácidos graxos e valor calórico de cinco espécies de peixes marinhos nas diferentes estações do ano. Rev. Inst. Adolfo Lutz, 54, 27-35.

De Man, J. C.; Rogosa, M. and Sharp, M. E. (1960), A medium for the cultivation of lactobacilli. J. Appl. Bacteriol., 23, 130-135.

De Martinis, E. C. P. and Franco, B. D. G. M. (1997), Inhibition of foodborne by bacteriocin-producing Leuconostoc spand Lactobacillus sake isolated from "lingüiça frescal". Rev. Microbiol., 28, 284-287.

Gonzáles-Fernandez, C.; Santos, E. M.; Jaime, I. and Rovira, J. (1997), Utilización de cultivos iniciadores en la elaboración de chorizo y su influencia en las propriedades sensoriales. Food Sci. Tech. Int., 3, 31-42.

Gory, L.; Montel, M. C. and Zagorec, M. (2001), Use of green fluorescent protein to monitor Lactobacillus sakei in fermented meat products. Microbiol. Lett., 194, 127-133.

Ijong, F. G. and Ohta, Y. (1996), Physicochemical and microbiological changes associated with Bakasang processing - A traditional Indonesian fermented fish sauce. J. Sci. Food Agric., 71 : (1), 69-74.

Lewus, C. B.; Kaiser, A. and Montville, T. J. (1991), Inhibition of food-borne bacterial pathogens by bacteriocins from lactic acid bacteria isolated from meat. Appl. Environ. Microbiol., 57, 1683-1688.

Morzel, M.; Fransen, N.G. and Elke, K.A. (1997). Defined starter cultures used for fermentation of salmon fillets. J. Food Sci., 62 : (6), 1214-1218.

Olympia, M.; Ono, H.; Shinmyo, A. and Takano, M. (1992). Lactic acid bacteria in a fermented fishery product, "Burong Bangus". J. Ferment. Bioengin., 73 : (3), 193-197.

Ostergaard, A.; Embarek, P. K. B.; Wedell-Neergaard, C.; Huss H. H. and Gram, L. (1998). Characterization of anti-listerial lactic acid bacteria isolated from Thai fermented fish products. Food Microbiol., 15 : (2), 223-233.

Twddy, D. R.; Cross, S. J. and Cooke, R. D. (1987). Parameters involved in the production of lactic acid preserved fish-starchy substrate combinations. Int. J. Food Technol., 22, 115-121. 
Virulhakul, P. (2000). The processing Thai fish sauce. Inf. Int., 5 : (2), 49-53.

Zhang, G. and Holley, R. A. (1999). Development and PFGE monitoring of dominance among spoilage lactic acid bacteria from cured meats. Food Microbiol., 16, 633-644.

Roig-Sagués, A. and Eerola, S. (1997), Biogenic amines in meat inoculated with Lactobacillus sake starter strains and an amine-positive lactic acido bacterium. Food Res. Technol., 205 : (3), 227-231.

Silva, C. C. G.; Ponte, J. B. and Dapkevicius, M. L. N. E. (1998), Storage temperature effect on histamine formation in big eye tuna and skipjack. J. Food Sci., 63 : (4), 644-647.

Statsoft Inc. Stat. For Windows [Computer Program Manual] Tulsa, OK : Statsoft Inc.www.statsoft.com. 